\title{
Chapter 7 \\ The Uaratio and its Possible Use in Roman Urban Planning to Obtain Astronomical Orientations
}

\author{
Andrea Rodríguez-Antón \\ Instituto de Astrofísica de Canarias \& Universidad de La Laguna, Spain [ara@iac.es]
}

Margarita Orfila Pons

Universidad de Granada, Spain [orfila@ugr.es]

\author{
A. César González-García \\ Instituto de Ciencias del Patrimonio, Incipit-CSIC, Spain [a.cesar.gonzalez- \\ garcia@incipit.csic.es]
}

Juan A. Belmonte

Instituto de Astrofísica de Canarias \& Universidad de La Laguna, Spain [jba@iac.es]

Abstract Several works have tried either to demonstrate or reject the notion that the orientation of the main axis of a Roman city was deliberate since its choice might add an extra sacred dimension to the entire urban space (González-García et al. 2014; Magli 2008). There exist ancient texts that support the hypothesis of the existence of astronomical orientations, such as those of Frontinus ( $D e$ Agrimmensura, 27) or Hyginus Gromaticus (Constitutio,I). In the case that these precepts were fulfilled: how to achieve it? Besides the astronomical hypothesis, some scholars have pointed to the use of a geometrical technique: the uaratio (Orfila et al. 2014). By this, the short sides of a regular triangle that are in ratios of integer numbers (for example 1:2, 2:3) are laid along the cardinal axes. In this work we present a comparison of the orientation of 81 Roman towns in the Iberian Peninsula, measured in situ, with uaratio angles with aspect ratios up to 12:12. By this exercise we want to discern whether the orientations were astronomical, purely geometrical, or if geometry could have fostered astronomical aims by using selected and well-known angles to trace lines that fitted the desired astronomical purposes. It is then, an attempt to shed more light to the issue of the orientation of Roman towns by combining two hypotheses that, in contrast to what it might seem, could be complementary but not contrary.

\subsection{Introduction}

Roman society is characterised, among other factors, by the incorporation of norms used in daily life in measuring units, in time reckoning and in modular division when constructing buildings. These norms also were applied during the division and careful planning of conquered or confiscated territory.

At that time, land division played a key role in the expansionist process and was essential in reorganizing the territory after a conquest, when new structures, such as towns, were erected. The foundation or re-foundation of towns involved important decisions about their spatial organization and orientation (Orfila et al. 2017a). Furthermore, Romans accepted the idea of well-planned cities, and urban organization was applied with common standards and objectives. Importantly, it provided a reliable means of calculating the taxes that should be collected per each plot of land (Gilman Romano 2013).

Land division was carried out by a number of individuals: the curator operis, who coordinated the project, the architectus or mensor who defined the plan, and the gromatici or agrimensores, who laid out the divisions. They also measured irregular plots, understood the complexities of land law, and by the Late Empire even became judges in land disputes (Lewis 2001). Each plot of land, or centuria, was demarcated by limites or roads at right angles known as decumani and cardine that, ideally, should run east-west and north-south, respectively. However, previous studies have revealed that cardinal orientation was not a common trend (González-García and Magli 2015; González-García et al. 2014; Orfila et al 2014). 
Besides the practical component, a symbolic aspect should not be dismissed, since the creation or a new territorium contained an ideological factor (Castillo Pascual 1996). The foundation of new urban entities was accompanied by the performance of a ritual that might have influenced the selection of the spatial disposition of the main axes (Ryckwert 1988). In this sense, by considering a combination of practicality, adaptation to the terrain conditions and symbolism, an unavoidable question arises about the motivations that were used in selecting the orientation of Roman urban grids.

Although some of the first publications on this topic (Le Gall 1975; Peterson 2007) refused to accept the existence of any intentionality behind the orientation of Roman towns, a number of later studies suggested the presence of well-defined patterns of orientation in different regions across the Roman Empire (Orfila et al. 2014; Richardson 2005). Furthermore, astronomy-based explanations for the orientation of many of the settlements in the studied samples were proposed by a number of authors (González-García and Costa Ferrer 2011; González-García et al. 2014, 2015). If this was so, how did Roman surveyors achieve these astronomical designs?

In this work we propose a geometrical method that Roman topographers might have applied to urban layout in order to set the direction of the streets according to some celestial events. It consists of the application of a geometrical technique used in Roman times and explained by the ancient writer Nypsius: the uaratio. Basically, this technique is based on the use of right-angled triangles where the length of its short sides are in ratios of integer numbers or where the lengths of the three sides are in ratios of integer numbers. These last are called Pythagorean triangles because their sides form a Pythagorean triple (like 3:4:5 for instance, that obey the Pythagoras Theorem).

The possible use of a standardized geometrical method to determine the orientation of Roman towns has been explored previously (Orfila 2012; Orfila and Moranta 2001; Orfila et al. 2014, 2017b). In order to test this hypothesis, we compared the orientations of 76 Roman settlements in the Iberian Peninsula, which were measured in situ, with a set of uaratio angles. This test was complemented by the results of practical experiments with reconstructions of instrumentation used by the agrimensores, such as the groma, metae and a gnomon, developed by the SOTOER group at Universidad de Granada (Costa and Orfila 2014; Orfila et al. 2014).

If the astronomical and the geometrical hypotheses converge, we might have found a relatively simple technique that worked as a standard procedure in the various processes of expansion (Adams 1982).

\subsection{The Uaratio: A Proposal for its Implementation}

The uaratio was a technique used by Roman topographers, and was described by Marcus Iunius Nypsius in the second century CE (Fluminis uaratio; Limitis Repositio: La. 285.1-295.15, Bouma 1993). Its application allowed the identification of the limites of the land lots assigned to each community. It was also useful in determining the orientation of every orthogonal project when the land lots were not cardinally oriented (Orfila et al. 2017; Roth Congés 1996). These interpretations are included in the Corpus of the Gromatici Veteres, which Chouquer (2004) interpreted and associated with the cadastre (land registry) that was made after the fire at the Roman archivum in CE 80, under Vespasian. In this, the location and limits of the different pieces of land was recorded.

On the basis that every architectural endeavour must start from a primordial line, we assume that this line was the meridian, as proposed by some scholars (see e.g. Orfila and Moranta 2001; Orfila et al. 2014, 2017b). The meridian line does not depend on the site location, and it is relatively easy to obtain by using a gnomon. This procedure is described by ancient authors such as Vitruvius (De Architectura I, 6.6) and Hyginus Gromaticus (Constitutio I, 52.4-22). As mentioned above, in most cases the urban axes were not cardinally oriented but were at different angles to the meridian line. Our proposal is that this may have originated from the use of the uaratio, as described below.

We follow Orfila et al. (2014) and consider two possible ways that this technique could have been applied. The first one consists of tracing the sides of a right-angled triangle whose sides are in integer aspect ratios [?] on the cardinal axes, as shown in Fig. 7.1(3ab). The ratios are called uariationes. The hypotenuse of the resulting triangle defines the direction of one of the streets, and that would depend on the ratio chosen for the triangle sides. The perpendicular street could have been obtained by using a groma. ${ }^{1}$ 
Alternatively, this technique can be used by considering right-angled triangles whose sides are Pythagorean triples. ${ }^{2}$ Our proposal is that the hypotenuse was drawn along the meridian line and the sides of the triangle, both with lengths that used integer numbers, would define the direction of the urban grid as seen in Fig. 7.1(2ab) (see Orfila and Chávez-Álvarez 2014a). This idea was first proposed by Margarita Orfila and Luis Moranta (2001) for the lowest Pythagorean triples of 3:4:5 and 5:12:13. In addition, the fact that the use of fractions to obtain irrational numbers was common in Antiquity (Neugebauer, 1969; Peterson, 1992) constitutes further motivation to explore their possible application in determining astronomical orientations of centuriae and urban grids.

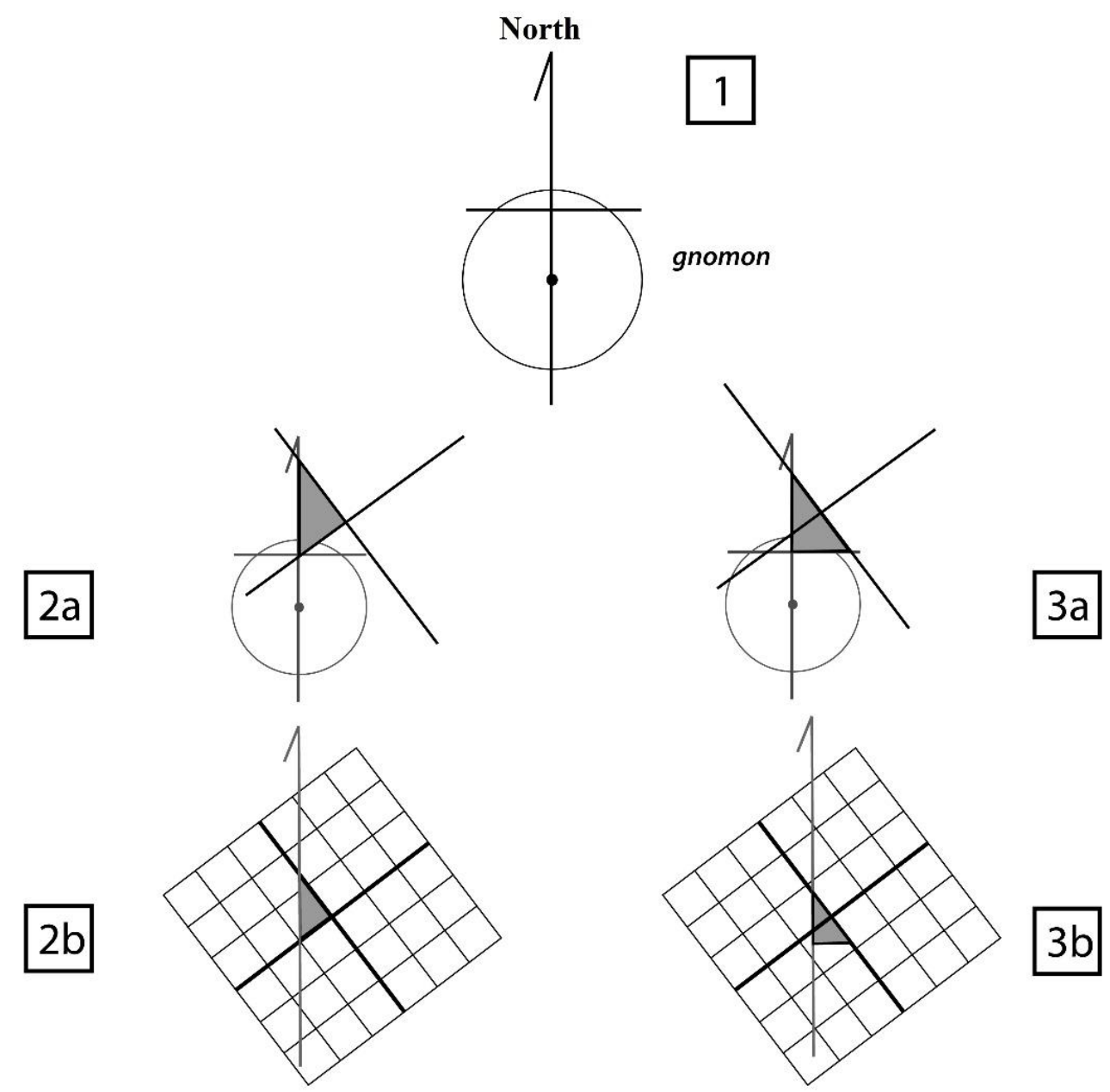

Fig. 7.1 The two hypothetical procedures for the application of the uaratio to obtain the direction of a new urban grid (adapted from Orfila et al. 2014)

\subsection{Sample and Methodology}

The first step was to test whether the uaratio was present in the city plans. To accomplish this, we compared the azimuth of the orientation of a number of Roman cities in the Iberian Peninsula with the distribution of uaratio angles.

This is an instrument based on a horizontal cross with arms in right angles, on a vertical support. From the end of each of the four arms hung a cord or plum-line tensioned by a bob. It was used for sighting and setting out straight lines and right angles (Lewis 2001).

2

These have three positive integers $(a, b, c)$ such that $a^{2}+b^{2}=c^{2}$. 
The sample contains the azimuths of the main streets of 76 Roman towns in ancient Hispania, corresponding to 81 orientations (Fig. 7.2) (Rodríguez-Antón 2017). This is due to the presence of more than one urban grid in some sites, such as Italica or Corduba. The data were collected in situ during several fieldwork campaigns (Rodríguez-Antón 2017). The altitude of the horizon in the direction marked by each city grid was also measured in order to compute the astronomical declination of a hypothetical object that would rise or set at that specific point on the horizon.

We used a professional compass to obtain the azimuths and a clinometer to measure the altitudes of the horizon. These instruments introduce nominal errors of $\pm 14^{\circ}$ and $\pm 12^{\circ}$ respectively. However, azimuth errors were sometimes larger owing to external factors, such as the preservation state of the structures under consideration. The measured azimuths were corrected for magnetic declination, which was either estimated from the model WMM2012, or updated ones, available at: https://www.ngdc.noaa.gov/geomagweb/\#declination. When altitudes could not be measured due to blocked horizons, we used reconstructions of the horizon from the Digital Terrain Model SRTM (Shuttle Radar Topography Mission) of NASA through the on-line panorama generator HeywhatsThat, available at: http://www.heywhatsthat.com/.

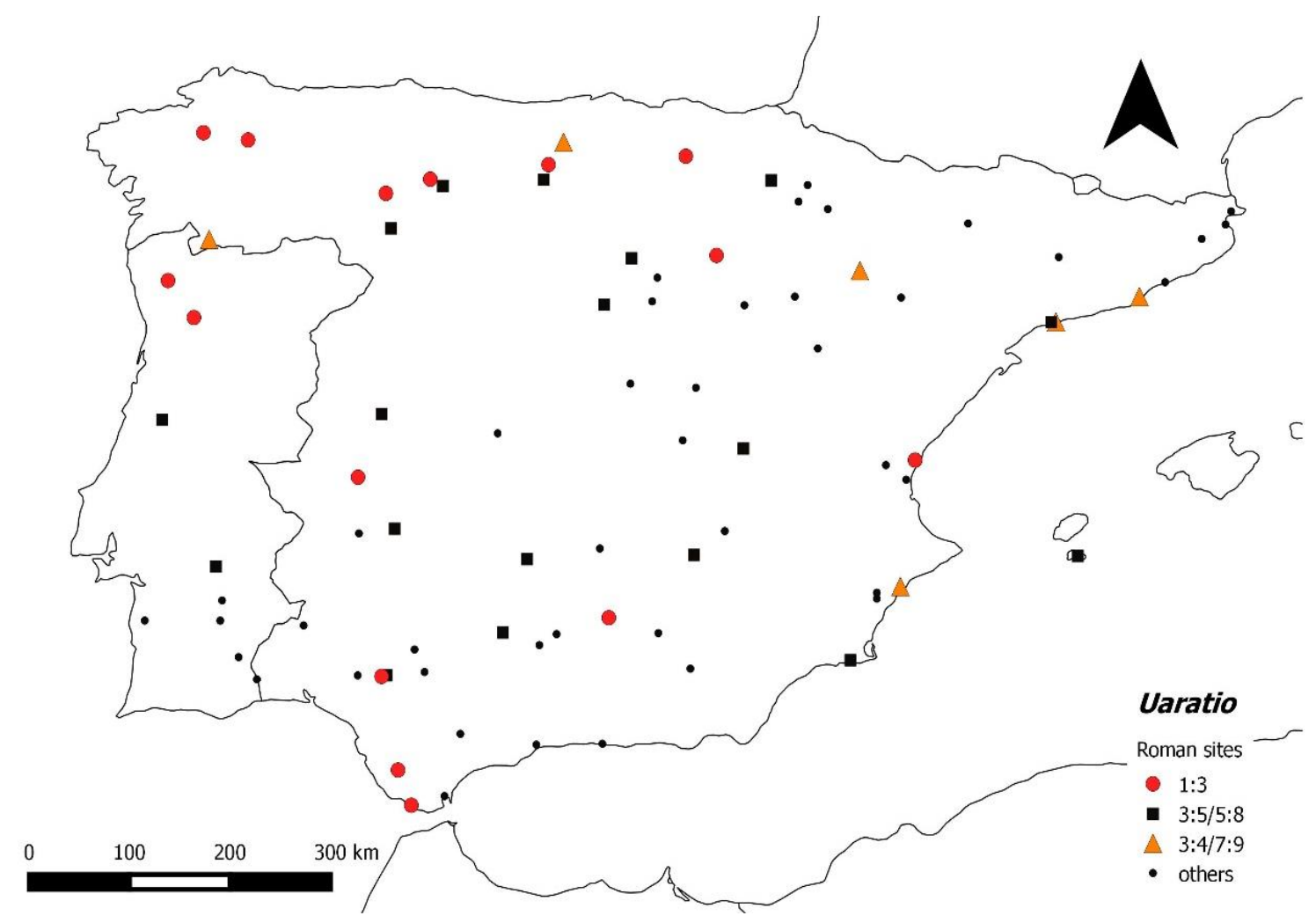

Fig. 7.2 Map showing the Roman cities studied, classified by the azimuth groups present in the sample that fit low uariationes

The comparison sample is a dataset of angles derived from the application of the uaratio as explained in the previous section. We considered uariationes ranging from 1:1 to 12:12. Since equivalent fractions correspond to equal angles, these were considered only once. That is, we did not include the angles resulting from, e.g., ratios 1:3, 2:6 and 3:9, but just those of 1:3 (Fig. 7.3). Fig. 7.4(a) shows the computed distribution of the uariationes computed from 1:1 to 12:12 across the entire horizon. 


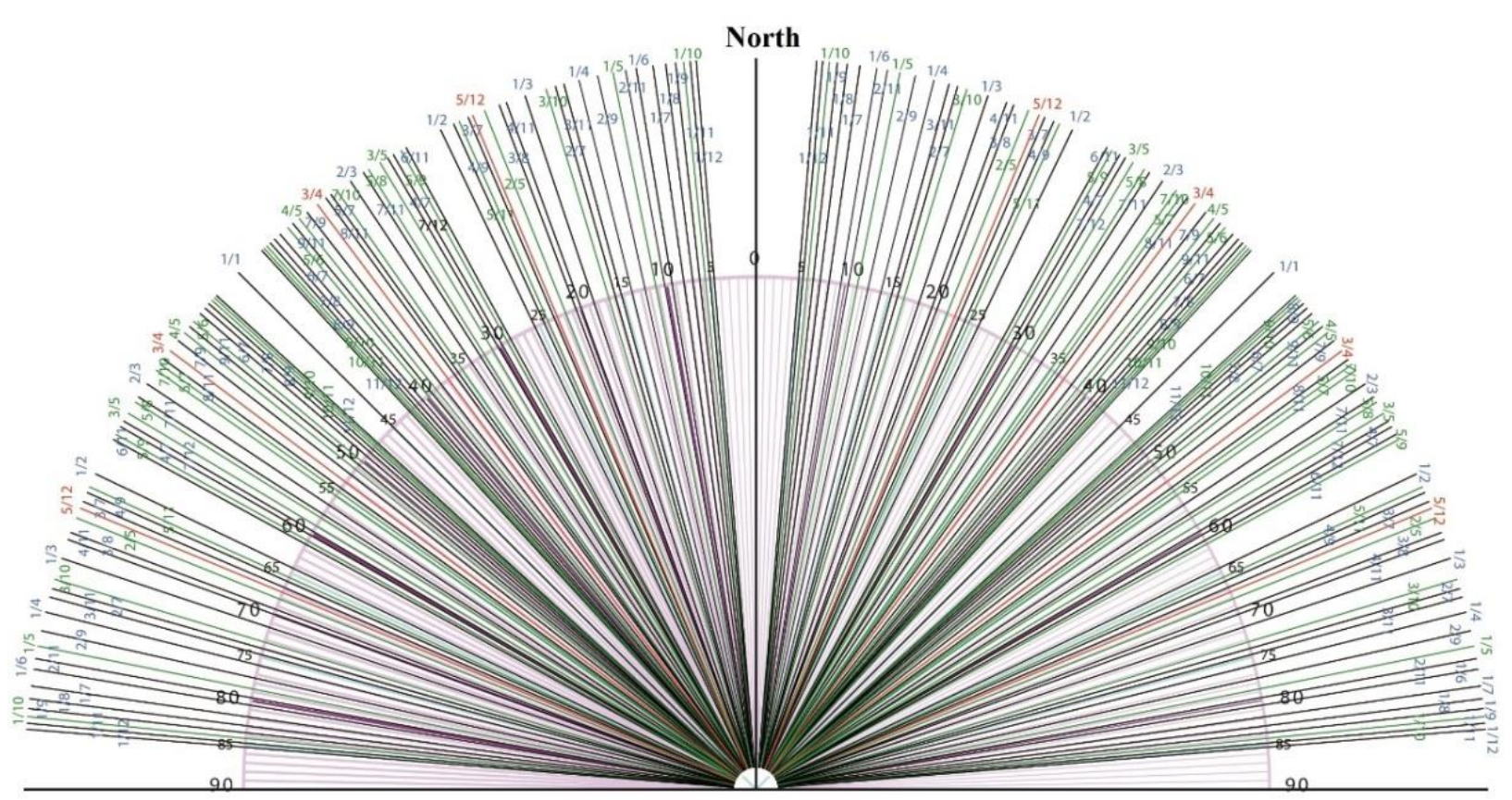

Fig. 73 Possible uariationes by using fractions from 1:1 to 12:12. 47 orientations per sector of $45^{\circ}$. Pythagorean uariationes in red (adapted from Orfila et al. 2014)
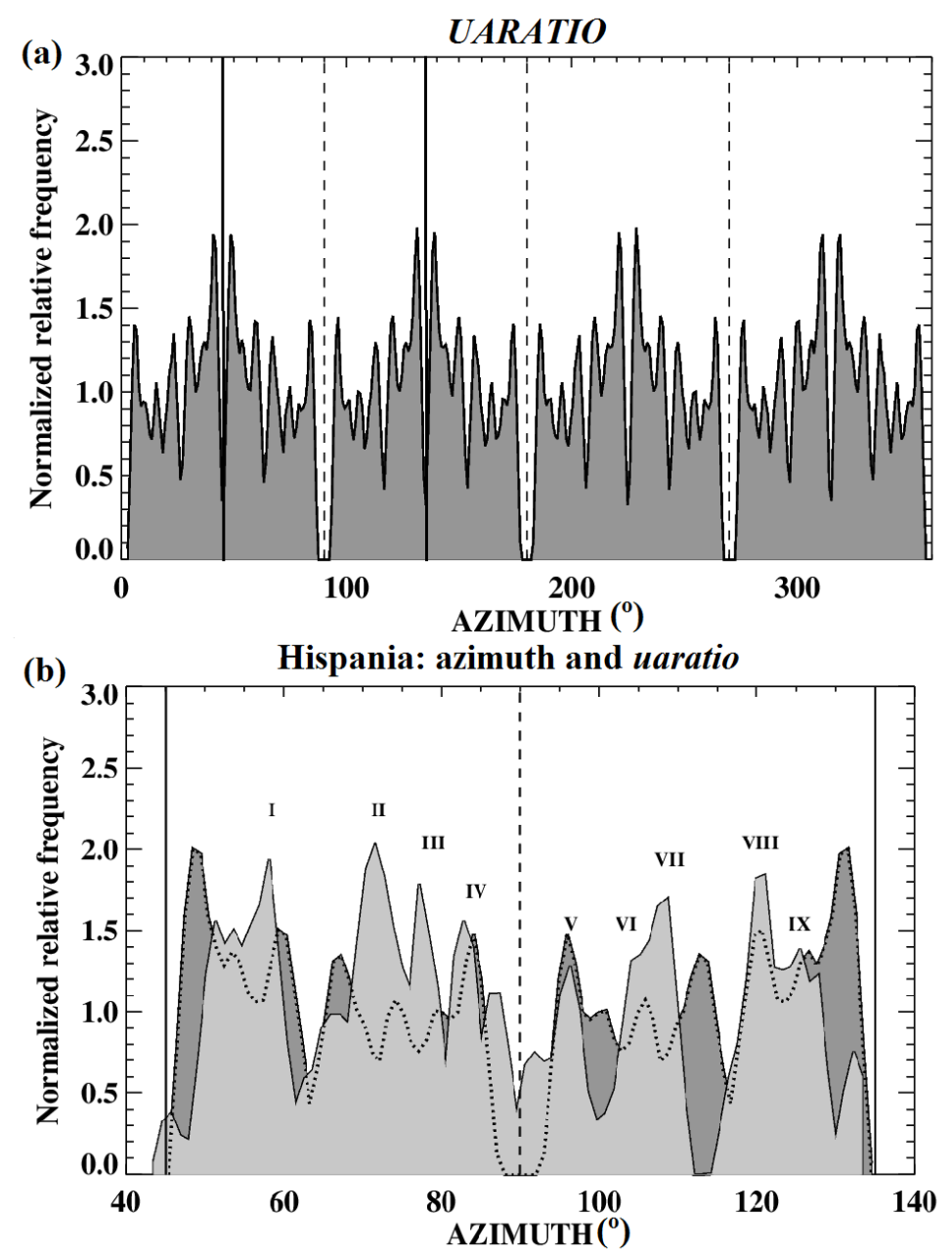

Fig.7.4 (a) Distribution of uaratio angles computed from uariationes 1:1 to 12:12. Equivalent proportions are considered just once. Dashed vertical lines indicate the cardinal points and solid vertical lines the interval of $90^{\circ}$ wide $\left[45^{\circ}, 135^{\circ}\right]$ chosen for Fig 7.4(b). (b) Distribution of uaratio angles from the interval indicated in Fig. 7.4(a) within vertical solid lines (dark grey) and the azimuths of the decumani of the 
sample of Roman towns in Hispania (light grey). Both distributions are the same in the three remaining symmetrical divisions. Roman numbers indicate the azimuth groups of the sample, whose equivalent values are shown in Table 7.1; read the text for further details

\begin{tabular}{|c|c|c|c|c|}
\hline \multirow[t]{2}{*}{ Maxima } & \multirow[t]{2}{*}{$\mathrm{A}\left({ }^{\circ}\right)$} & \multicolumn{2}{|c|}{ Uaratio } & \multirow[t]{2}{*}{$\begin{array}{l}\text { Equivalent } \\
\text { Maxima }\end{array}$} \\
\hline & & $\left({ }^{\circ}\right)$ & $\mathrm{X}: \mathrm{Y}$ & \\
\hline \multirow{3}{*}{$\mathrm{X}$} & \multirow{3}{*}{7} & 63 & $1: 9$ & \multirow{3}{*}{$\begin{array}{l}\text { IV } \\
\text { V }\end{array}$} \\
\hline & & 8.1 & $1: 7$ & \\
\hline & & 7.1 & $1: 8$ & \\
\hline \multirow{2}{*}{ XI } & \multirow{2}{*}{12} & 11.3 & $1: 5$ & \multirow{2}{*}{$\begin{array}{l}\text { III } \\
\text { VI }\end{array}$} \\
\hline & & 12.5 & $2: 9$ & \\
\hline XII & 18 & 18.4 & $1: 3$ & II/VII \\
\hline \multirow{4}{*}{ XIII } & \multirow{4}{*}{31.5} & 30.5 & $7: 12$ & \multirow{4}{*}{$\begin{array}{l}\text { I } \\
\text { VIII }\end{array}$} \\
\hline & & 30.9 & $3: 5$ & \\
\hline & & 32.0 & $5: 8$ & \\
\hline & & 32.5 & $7: 11$ & \\
\hline \multirow{4}{*}{ XIV } & \multirow{4}{*}{37} & 36.0 & $8: 11$ & \multirow{4}{*}{ IX } \\
\hline & & 36.9 & $3: 4$ & \\
\hline & & 38.5 & $4: 5$ & \\
\hline & & 37.9 & $7: 9$ & \\
\hline
\end{tabular}

Table 7.1 Values for angles of the maxima in the histogram in Fig. 7.5(a), uariationes that fit these angles, and in the last column equivalent peaks from Fig. 7.4(b)

A density distribution with an Epanechnikov kernel has been used to calculate the histograms in the present work. The bandwidth in each case depends on the sample size and the errors in the measurements, so that fine details can be appreciated while avoiding the over-smoothing of the distribution (GonzálezGarcía and Šprajc 2016). The value of the bandwidth is indicated in each particular case.

In the next section we will compare uaratio angles with azimuths (Fig. 7.4b), and angles bearing from north in the sample from Hispania with possible uariationes and angles from triangles in relation of Pythagorean triples (Fig. 7.5). Finally, we will compute the declinations of the orientations of the sample from Hispania to test whether the main values fit the use of simple uariationes (Fig. 7.6). 

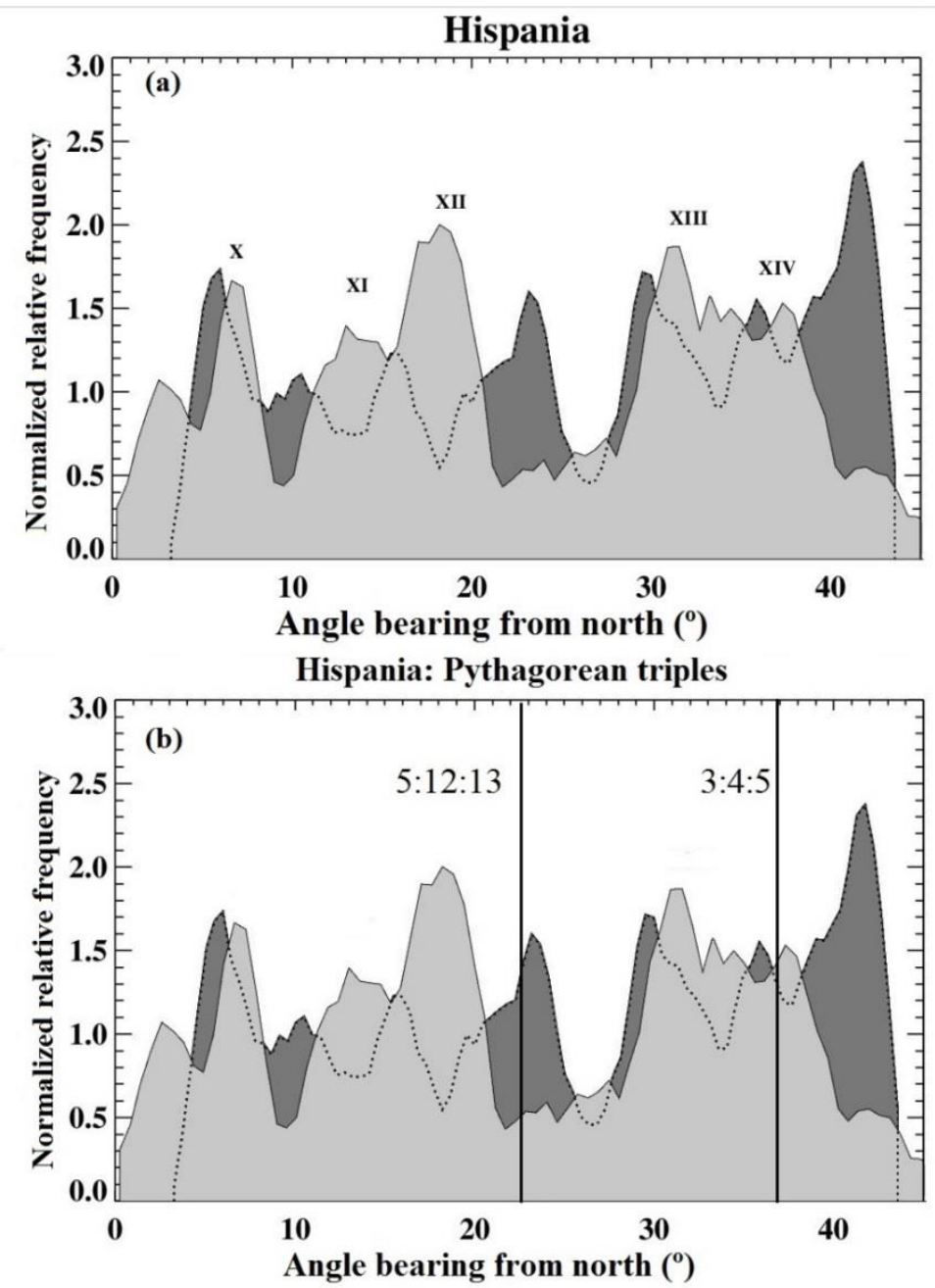

Fig.7.5 Histograms with the orientation of the angles bearing from north of the cities in the sample in Hispania (light grey) and uaratio angles within an interval of $\left[0^{\circ}, 45^{\circ}\right]$ (dark grey). Roman numbers in Fig. 7.5(a) are described in Table 7.1. Solid vertical lines in Fig. 7.5(b) indicate the equivalent angles by using Pythagorean triples to orientate towns

\subsection{Testing the Uaratio on Roman Settlements}

Due to the orthogonality of the street grids, the azimuth distribution, as well as the uaratio angles, are repeated four times along the $360^{\circ}$ of the horizon (Fig. 7.4a). This allowed us to limit the analysis to a $90^{\circ}$ wide sector in order to better appreciate the coincidence or divergences of both angle distributions (Fig. $7.4 \mathrm{~b}$ ). Due to the azimuth error, in general estimated in $\pm 0.5^{\circ}$, and the sample size (81 measurements) the bandwidth in the histograms in Fig. 7.4 is $1^{\circ}$. We established a margin of $\pm 2^{\circ}$ to consider that a ratio of uaratio fitted a city orientation. For that we took into account the intrinsic error of the azimuths and the irregularities that could have derived during the tracing of the meridian line and the triangles on the ground. 


\section{Eastern}
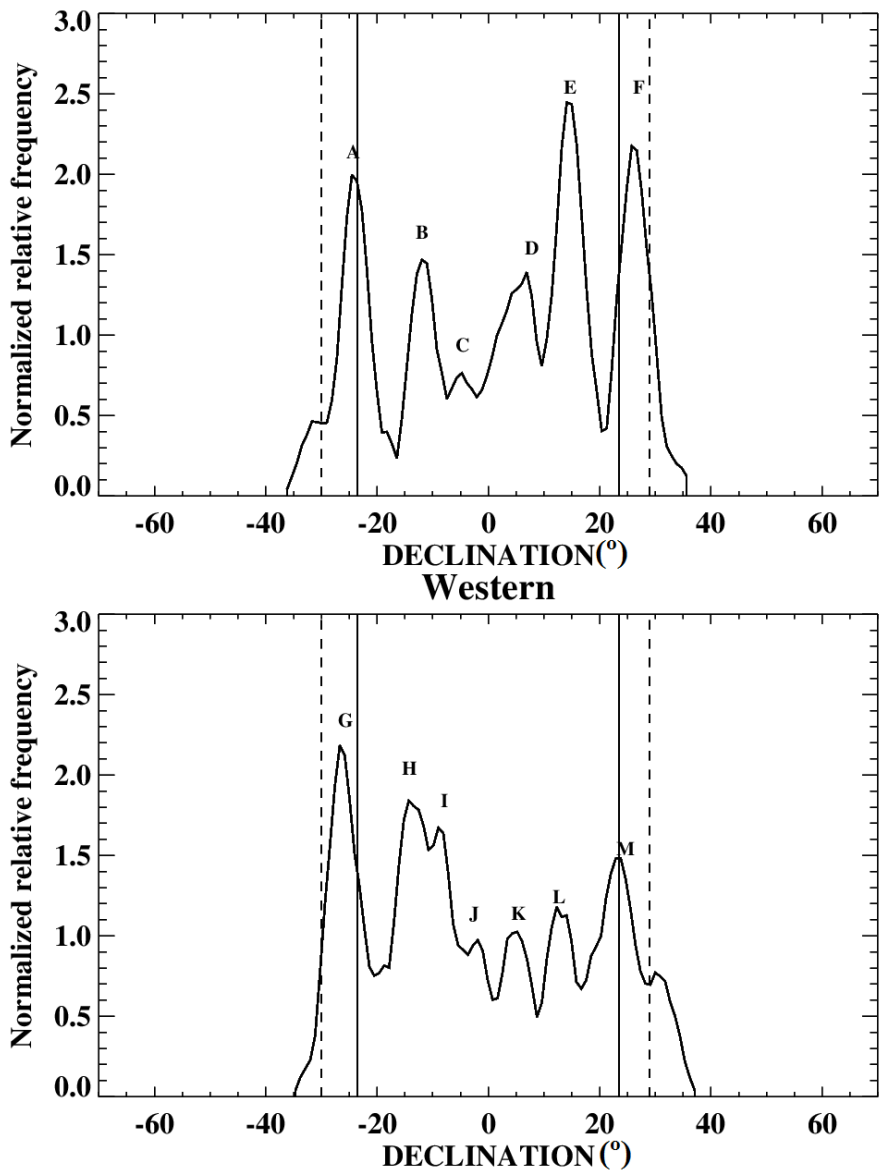

Fig. 7.6 Declination histograms of the decumani of the sample of Roman towns in Hispania, defined within azimuth sectors of $\left[45^{\circ}, 135^{\circ}\right]$ towards the east and $\left[225^{\circ}, 315^{\circ}\right]$ towards the west. Vertical solid lines represent the declination of the Sun at the solstices and dashed lines those of the Moon at its major lunastices

The election of the azimuth sector $\left[45^{\circ}, 135^{\circ}\right]$ is because we define a decumanus - the street that should run east-west - within that range and within its symmetrical interval towards the west $\left[225^{\circ}, 315^{\circ}\right]$. At latitudes of the Iberian Peninsula, both intervals comprise the azimuth sectors within which the Sun and the Moon move during a full solar or lunar cycle, so it is adequate to compare the azimuths of the decumani with solar positions. It is interesting to note that the azimuth distribution in Fig. 7.4b presents well-defined orientation groups, and that the main minima of the distributions of both datasets coincide. This means that there is a lack of cities oriented towards directions whose angles do not correspond to a uaratio proportion.

In order to further simplify the comparison, we took into account the symmetry of the uaratio angles within a $90^{\circ}$ sector. That is, we considered symmetrical proportions together (e.g., 1:3 and 3:1 are considered to be equal). Since in this study our main reference is the local meridian, we focused on the range $\left[0^{\circ}, 45^{\circ}\right]$. To take advantage of the mentioned symmetry, we converted the azimuths in the sector $\left[45^{\circ}\right.$, $\left.90^{\circ}\right]$ to the range $\left[0^{\circ}, 45^{\circ}\right]$ by considering their value relating to $45^{\circ}$ (called $\Phi$ ) and using the formula $\alpha=45^{\circ}$ $-\Phi$. Now $\alpha$ is the symmetric angle to $\Phi$ bearing from $45^{\circ}$ (Fig. 7.5). Angles in the range of $\left[0^{\circ}, 45^{\circ}\right]$ were left unmodified. We stress that with this choice in our analysis now concerns the application of particular proportions rather than the orientation of the town. The angles of the maxima of Fig. 7.5a and the possible uariationes that fit each azimuth are shown in Table 7.1. What is observed in the histograms in Fig. 7.5 is that symmetrical peaks relating to the cardinal points in Figure $4 \mathrm{~b}$ merge and give those wider maxima in Fig. 7.5 (Table 7.1).

To compute the histogram we used a density distribution with an Epanechnikov kernel with a bandwidth of $34^{\circ}$, since now there are more elements within a smaller interval and it is convenient in order to better appreciate fine details in the distributions. Once again, there is a coincidence of the main minima of both distributions. Furthermore, it is interesting to note that three of those maxima (XII, XIII and XIV, Table 7.1) fit angles that derive from relatively simple uariationes such as 1:3 or 3:4.

We next tested whether city azimuths matched the angles resulting from implementing right-angled triangles with sides in relation to Pythagorean triples 3:4:5 and 5:12:13. The reason for using these triples is 
that these are the lowest ones; that is, the ones that represent the smallest fractions. Additionally, these ratios were often used in Antiquity (Gros 1976; Orfila 2014; Roskams 2001). As can be shown in Fig. 7.5b, there is a quite appreciable group of azimuths that approximate to the equivalent angles of using 3:4:5, while not many match the angles resulting from 5:12:13.

Finally, we conducted a Kolmogorov-Smirnov test to broaden our understanding of the results and to check whether both datasets were drawn from the same parent population. That is, if the azimuths of these groups of Roman settlements could have been obtained by using the uaratio. If the resulting probability was low enough, the idea that both samples had the same origin could be excluded. A probability of 0.05 or smaller is required to dismiss this hypothesis with a confidence level of $95 \%$. In this case the test yields a probability of 0.14 , so we cannot discard the possibility that both samples come from the same parent population with sufficient confidence level.

\subsection{A Possible Link Between Uariationes and Astronomical Positions}

As seen above, the use of the uaratio to determine the orientation of new cities cannot be discarded. In case this was indeed a common practice, what could have motivated the election of specific angles?

Certain texts by ancient topographers such as Frontinus (De Agrimensura, 27) and Hyginus Gromaticus (Consitutio 1) contain practical recipes for land demarcation and surveys (Gilman Romano 2013). In particular, they indicate the necessity to follow the path of the Sun when orienting the decumanus of a town. The sacred character of this task and the performance of a ritual in the foundation of a new urban, or even military, space should not be underestimated either (Ryckwert 1988), and give support to the astronomical hypothesis for the orientation of towns. Furthermore, a number of studies also suggest that the main streets of several Roman towns could have been laid out according to some celestial phenomena, both in the Iberian Peninsula (e.g. Costa Ferrer and González-García 2011; González-García et al 2014, 2015) and in other regions of the Roman Empire (e.g. González-García and Magli 2015; Rodríguez-Antón et al. 2016a, 2016b).

In this exercise we have selected the lowest uariationes, or fractions, from Table 7.1 whose equivalent angles fit maxima of the sample present in the diagram in Fig. 7.5 and calculated the resulting declination in the direction of the hypothetical decumani that bear azimuths equal to these uaratio angles. We considered a flat horizon $\left(h=0^{\circ}\right)$ and latitudes of $40^{\circ}$ and $42^{\circ}$, because these are approximately the mean values for the Iberian Peninsula and Rome respectively.

By this, our aim was to check whether astronomical orientations were obtained by the standardized application of specific uariationes when observations of astronomical rises and sets could not be observed directly. The idea of comparing the declinations for the latitude of Rome arises from the possibility that, in case the uaratio were actually used to point towards particular celestial objects, the Urbs might have been the reference places when the standards were stablished and later exported to different regions.

Assuming that the application of uariationes that involved low proportions would have been easier, and thus more common, we began this test by exploring the resulting declination values from the use of the simplest ratios that fitted some of the maxima of the azimuth in the sample. In particular, we calculated the declination of hypothetical decumani whose azimuths coincided with the corresponding angles of using the lowest uariationes in Table 7.1. From the peaks in Fig. 7.5, the orientation groups of the sample that derived from low uaratio proportions were XII (1:3), XIII (3:5) and XIV (3:4 or 4:5). Maxima X and XI coincide with angles that result from bigger proportions; maybe with the exception of 1:5 in XI.

It should be highlighted that because of the estimated error margin to differentiate an azimuth from a uaratio proportion ( of $\pm 2^{\circ}$ ), and the significant density of possible uaratio angles within each interval of $45^{\circ}$ width, there is normally more than one fraction associated with each azimuth. In these cases we tend to assume that the lower the relation of the triangle sides, the more common the use of that fraction.

It must be stressed that not all the angles in Fig. 7.5 and Table 7.1 are real azimuths, but are angles bearing from north regardless of whether they were to the right or left of the meridian line. For this reason, and because our interest is to compare these values with those of the decumani, we have used the azimuths shown in Fig. $7.4 \mathrm{~b}$ to compute the declinations, within $\left[45^{\circ}, 135^{\circ}\right]$, which are equivalent to those shown in Fig. 7.5 and listed in Table 7.1.

For example, the value of maximum XII (Fig. 7.5a, Table 7.1), which is centred on $18^{\circ}(\alpha)$, approximates to that of the proportion 1:3. Due to the symmetry regarding cardinal points, this fraction comprises peaks II and VII in Fig. 7.4b, which derive from 3:1 and 1:3, respectively. In this way, the azimuths considered to relate to the declination were $72^{\circ}\left(90^{\circ}-\alpha\right)$ and $108^{\circ}\left(90^{\circ}+\alpha\right)$, that resulted in $\delta \approx$ 
$\pm 13.5^{\circ}$ at latitude $40^{\circ}$ and $\delta \approx \pm 13.25^{\circ}$ at latitude $42^{\circ}$. In the map shown in Fig. 7.2 there is a concentration of cities that bear these azimuths in northern Hispania, while the rest are spread in the south, with just one in the Levantine coast.

Following the same criteria, maximum XIII (Fig. 7.5a), which is centred on $31.5^{\circ}$ (Table 7.1), is associated with simple proportions such as 3:5, as well as 5:8, 7:11 and 7:12, and comprises the symmetrical maxima I and VII in Fig. 7.4b. The resultant declinations are $\delta \approx \pm 23.5^{\circ}$ at latitude $40^{\circ}$ and $\delta \approx$ $\pm 22.75^{\circ}$ at latitude $42^{\circ}$. Sites with this orientation are spread throughout the entire Iberian territory.

The last maximum analysed is XIV (Fig. 7.5), whose angle can be associated with uariationes 3:4 and 4:5, which are relatively simple, as well as sides of the Pythagorean triple 3:4:5. The resultant declination does not fall within a solar range but in a lunar one. The declinations are now $\delta \approx \pm 27.25^{\circ}$ at latitude $40^{\circ}$ and $\delta \approx \pm 26.5^{\circ}$ at latitude $42^{\circ}$.

As can be observed from the histograms in Fig. 7.6, all of the formerly mentioned declination values correspond to the most significant maxima present in the studied sample. The declinations of peak XII approximate maxima B, E, H and L in Fig. 7.6, whose values coincide with that of the Sun on last days of April and October. Peak XIII gives solstitial or almost solstitial declinations and, as already mentioned, the resultant values for peak XIV offer declinations out of the solar range. To represent the histograms in Fig. 7.6 we have used an Epanechnikov kernel with a bandwidth of $1.5^{\circ}$, following the same criteria that we used in Figs. 7.4 and 7.5. Interestingly, the uariationes that fit the values of maxima X and XI, which involve higher proportions than those of XII, XXX and XIV (Table 7.1), give the less significant declinations groups of Fig. 7.6: C, D, J and K.

Finally, the same procedure was followed with the triangles in relation to the lowest Pythagorean triples: 3:4:5 and 5:12:13 if they were used as proposed in Fig. 7.1(2ab); that is, if the hypotenuse was drawn along the meridian line. For the triple 3:4:5 the resultant declinations were $\delta \approx \pm 27.25^{\circ}$ at latitude $40^{\circ}$ and $\delta \approx \pm 26.5^{\circ}$ at latitude $42^{\circ}$. In the case of using 5:12:13, the results were $\delta \approx \pm 17^{\circ}$ at latitude $40^{\circ}$ and $\delta \approx$ $\pm 16.5^{\circ}$ at $42^{\circ}$. As expected, values from 3:4:5 give the same declination as maximum XIV. The resulting declinations by using a triple 5:12:13 coincide with positions of the Sun on the first days of February and August and in mid-November and May.

\subsection{Discussion}

The fact that some azimuths in the sample give declinations for a flat horizon similar to the real ones in the Hispanic sample is not a surprise but something that one may expect. It is obvious as well that almost all the azimuths matched the uaratio angles, due to the high density of uariationes within an interval of $45^{\circ}$ wide. However, the striking result is that the main declination groups of the sample (Fig. 7.6) coincide with significant dates when the Sun had azimuth values that resulted from the use of low uariationes (maxima XII, XIII and XIV). Furthermore, these declination groups are the same ones that contain the most significant astronomical relationships for the Roman context in Hispania (González-García et al. 2014).

In the first case, we observed that the fraction 1:3 (peak XII, Fig. 7.5) gives declinations at the studied latitudes that can be roughly associated with the position of the Sun on the day of the mythical foundation of Rome (21April) or 1 May (as well as 1 November and 1 February for its negative value). In the case of 21 April, the connection with the Roman tradition is certainly obvious, but for the other dates, a reasonable explanation arises from pre-Roman traditions. In particular, these can be related to the so-called Celtic midseason festivals (García Quintela and González-García 2017). This hypothesis makes sense for the group of cities in the Iberian northwest that bear azimuths from group XII (Fig. 7.5a), for being a region traditionally considered to have been inhabited by local societies with a Celtic substratum. In addition, similar results had been found in other regions with ancient Celtic traditions, such as Galia (García Quintela and González-García, 2016; González-García and García Quintela 2014; González-García et al. 2016) or Germania (Espinosa Espinosa et al. 2016). We thus have found simple uariationes that relate to relevant astronomical orientations.

The second interesting result is that of peak XIII, which gives roughly solstitial declinations that are also present in the histograms in Fig. 7.6, and in the orientation patterns of Roman towns studied in other areas of the Empire (González-García and Magli 2015; González-García et al. this volume; RodríguezAntón et al. 2016b), that were explained by the symbolism of Augustus's propaganda, among other possibilities. In fact, $50 \%$ of towns that bear this azimuth have Augustan foundations or re-foundations: Petavonium, Pisoraca, Valeria, Liberalitas Iulia and the Imperial urban grids of Corduba and Tarraco. Once again, low proportions, such as the 3:5, give conspicuous astronomical patterns. 
Finally, the use of the fraction 3:4 could have been applied to obtain orientations outside the solar range, like in the two maxima at $\delta \approx \pm 27^{\circ}$ present in the declination histogram (F, G in Fig. 7.6). One hypothesis connects this result with the Julio-Claudian dynasty, because the goddess Venus was regarded as the ancestral mother of the Gens Iulia, which Cesar and Augustus belonged to. There are three cities from this period with an azimuth of 3:4:5: Juliobriga, Cesaraugusta and Barcino, all in northern Hispania (Fig. 7.2). Similar values were also obtained in some Roman towns in North Africa (Rodríguez-Antón et al. 2017). In this particular case, some were explained by positions of the Moon and Venus as well, having also Uthina and Thuburbo Majus Augustan foundations (see González-García et al. this volume). However, it is just an hypothesis and a deeper analysis of these values is needed.

It must be stressed that not all the cities grouped in a declination pattern have the same azimuth, since the horizon is not always flat. There are also sites oriented according to some of the listed uaratio angles, for example 3:5, that have different declination values from those predicted for the selected latitudes and flat horizons. One example is that of the Roman theatre at Carthago Nova (present-day Cartagena), where the frons scenae and cavea line follows a solstitial azimuth that could have been drawn by the application of proportion 3:5 elsewhere or transported from the forum of the city (González-García et al., 2015), but the structure itself does not point to the real sunrise at the summer solstice due to the local topography.

In particular, just $57 \%$ of the cities in the declination group E have an azimuth that could be obtained by using a 1:3 relation and $66 \%$ of those with a solstitial declination have an azimuth corresponding to a fraction 3:5.

In the case of the relation 3:4, it is present in six cities with almost solstitial orientations or close to the extreme declination of Venus as a morning $\operatorname{star}\left(\delta \approx \pm 24^{\circ}\right)$, and in eight towns where the decumani point towards extremes of Venus as an evening star $\left(\delta \approx \pm 27^{\circ}\right)$.

As a matter of fact we find sites with astronomical declinations and with azimuths derived from low uariationes, but there are also cities with the same declination but different azimuth values. In this last case, orientations might have been obtained by direct observation of astronomical phenomena. One example would be the orientation of Via Appia, where it seems that the Romans chose the setting of the star Castor as the direction where the via should face instead of the use of a simple fraction (1/1) (Magli et al. 2014). In this scenario, it is difficult to discern in cases where:

(1) Direct astronomical observations give similar azimuths.

(2) The orientations considered as astronomical resulted from the application of specific uariationes.

(3) Standardised relations between uariationes and astronomical positions did exist so those fractions were used when direct observations of the astronomical phenomena were not possible.

\subsection{Conclusions}

In this analysis we have explored whether a standardised geometrical technique was used by ancient Roman topographers to set specific directions of land plots and, in particular, of city grids. By this, we can enumerate a couple of main outcomes:

(1) The coincidence of the main minima of both distributions, uaratio angles and azimuths of the sample, suggests that there is a lack of orientations towards directions that are not associated with a uaratio proportion. Furthermore, the result of the Kolmogorov-Smirnov test does not allow us to refute the null hypothesis that both datasets come from the same parent population. That is, it is not possible to discard the idea that the azimuths were obtained by the use of the uaratio with a sufficient level of confidence.

(2) Secondly, the azimuth groups of the sample that can be obtained by the application of low uariationes (XII, XIII and XIV) and the Pythagorean triple 3:4:5 give declination values that coincide with the main declination groups of the sample as well as with interesting astronomical positions within a Roman context. That is, there is an agreement between simple uariationes and relevant astronomical orientations present in the sample in Hispania. Conversely, maxima X and XI fit the angles of higher uariationes such as 1:9 and $2: 9$, and currently the resulting declinations cannot be explained by the relevant positions of any celestial bodies.

In the light of this, although sometimes orientations seem to hint an astronomical use of the uaratio, to better understand these results, an analysis of a wider sample at different latitudes, or restricted to delimited areas, is needed. Besides this, it would be also interesting to examine more local or chronological 
conditions, in order to determine whether astronomical motivations may have been favoured over more practical ones.

To sum up, it could be said that currently we cannot refute the use of a geometrical technique such as the uaratio to explain the orientation of Roman rural and urban spaces. In fact, this procedure could have been something extremely useful to obtain the characteristic regular organization of Roman landscapes according to the sky, since only the determination of the meridian line would have been needed to repeat the same orientation across the different territories. Furthermore, if a connection between the uariationes and the positions of some celestial bodies did really exist, geometry and astronomy might have represented a combination of practicality and symbolism when direct observations of the celestial phenomena in question were not possible.

Acknowledgments. We express our gratitude to those who collaborated in the elaboration of this study: Esther ChávezÁlvarez, Luis Moranta, Elena H. Sánchez, Mario Gutiérrez and Aránzazu Medina. We also thank David Martín Belda for fruitful discussions. This work has been financed under the framework of the projects P/310793

'Arqueoastronomía' of the IAC, and AYA2015-66787 'Orientatio ad Sidera IV' and HAR2013-41635-P, of the Spanish MINECO.

\section{References}

Adam, J.P. (1982). Groma et chorobate. Exercices de topographie antique. Mélanges de l'École Française de Rome, Antiquité, 94, 1003-1029.

Bouma, J. (1993). Marcus Iunius Nypsus. Fluminis Varatio, Limitis Repositio. Introduction, Text, Translation and Commentary. Frankfurt/Main: P.Lang (Studien zur Klassischen Philologie, 77).

Castillo Pascual, Maj. (1993). Agrimensura y agrimensores: el Corpus agrimensorum Romanorum. Hispania Antiqua, 17, 143-158.

Castillo Pascual, Maj. (1996). Espacio de orden: El Modelo Gromático-Romano de Ordenación del Territorio. Logroño: Universidad de La Rioja.

Chouquer, G. (2004).Une nouvelle interprétation du Corpus des Gromatici Veteres'. Agri Centuriati, 1, $44-56$.

Costa, V., \& Orfila, M. (2014). Creación física de gnómones. In M. Orfila, E. Chávez-Álvarez, \& E.H. Sánchez (Eds.), La Orientación de las Estructuras Ortogonales de Nueva Planta en Época Romana (pp. 129-155). Granada: Universidad de Granada-Universidad de La Laguna.

Espinosa Espinosa, D., González-García, A.C., \& García Quintela, M.V. (2016). On the orientation of Roman towns in the Rhine area. Mediterranean Archaeology and Archaeometry, 16(4), 233-240.

Gilman Romano, D. (2003). City planning, centuriation and land division in Roman Corinth: Colonia Laus Iulia Corinthiensis \& Colonia Iulia Falvia Augusta Corinthiensis in Corinth, 20, Corinth, The Centenary: 1896-1996. The American School of Classical Studies, 279-301.

González-García, A.C., \& Costa Ferrer, L. (2011). The diachronic study of orientations: Mérida a case of study. In C.L.N. Ruggles (Ed.), Archaeoastronomy and Ethnoastronomy: Building Bridges Between Cultures (pp. 374-381). Cambridge: Cambridge University Press.

González-García, A.C., \& García Quintela, M.V. (2014). The $1^{\text {st }}$ of August at Lugdunum: astronomy and Imperial cult in Galia. Mediterranean Archaeology and Archaeometry, 14(3), 83-91.

González-García, A.C., \& Magli, G. (2015). Roman city planning and spatial organization. In C.L.N. Ruggles (Ed.), Handbook of Archaeoastronomy and Ethnoastronomy (pp. 1643-1650). Heidelberg: Springer.

González-García, A.C., \& Šprajc, I. (2016). Astronomical significance of architectural orientations in the Maya lowlands, a statistical approach. Journal of Archaeological Sciences: Reports, 9, 191-202.

González-García, A.C., Rodríguez-Antón, A., \& Belmonte, J.A. (2014). The orientation of Roman towns in Hispania: preliminary results. Mediterranean Archaeology and Archaeometry, 14(3), 107-119.

González-García, A.C., García Quintela M.V., \& Belmonte, J.A. (2016). Landscape construction and time reckoning in Iron Age Celtic Iberia. Documenta Praehistoria, 43, 479-497.

González-García, A.C., Rodríguez-Antón, A., Espinosa Espinosa, D., García Quintela, M.V., \& Belmonte, J.A. This volume. Establishing a new order: the orientation of Roman towns at the Age of Augustus.

González-García, A.C., Noguera Celdrán, J.M., Belmonte Avilés, J.A., Rodríguez-Antón, A, Ruiz Valderas, E., Madrid Balanza, M.J., Zamora, E., \& Bonnet Casciaro, J. (2015). Orientatio ad sidera: astronomía y Paisaje urbano en Qart Hadašt/Carthago Nova. Zephyrus, 75, 141-162. 
Gotarelli, A. (2004). Templum Solare e città fondata. La connessione astronomica della forma urbana della città etrusca di Marzabotto (III). In A. Sasatelli, \& E. Govi (Eds.), Culti, Forma Urbana e Artigianato a Marzabotto. Nuove Prospettive di Ricerca (pp. 101-138). Bologna: Università di Bologna.

Gros, P. (1976). Nombres irrationnels et nombres parfaits chez Vitruve. Mémoires de l'Ecole Française de Roma, Antiquité, 88(2), 669-704.

Guy, M. (1993). Les orientations des parcellaires quadrillés. Revue Archéologique de Narbonnaise, 26, $57-68$.

Le Gall, J. (1975). Les Romains et l'orientation solaire. Mélanges de l'École Française de Rome, Antiquité, $87,287-320$.

Lewis, M.J.T. (2001). Surveying Instruments in Ancient Greece and Rome. Cambridge: Cambridge University Press.

Magli, G. (2008). On the orientation of Roman towns in Italy. Oxford Journal of Archaeology, 21(6), 63-71.

Magli, G., Realini, E., Reguzzoni, M., \& Sampietro, D. (2014). Uncovering a masterpiece of Roman engineering: the project of Via Appia between Colle Pardo and Terracina. Journal of Cultural Heritage, 15, 665-669.

Neugebauer, O. (1969). The Exact Sciences in Antiquity. New York: Dover

Orfila, M. (2011). Arqueología experimental aplicada al urbanismo. Un procedimiento para trazar y orientar estructuras ortogonales en época Romana. In A.Morgado, J. Baena, \& D. García (Eds.), La Investigación Experimental Aplicada a la Arqueología (pp. 289-297). Granada: Universidad de Granada.

Orfila, M. (2012). Un posible sistema para orientar estructuras de trazado ortogonal en época clásica. El caso de Pollentia (Mallorca, España). Geographia Antiqua, 20-21, 123-136.

Orfila, M., \& Moranta, L (2001). Estudio del trazado regulador del Foro de Pollentia (Alcúdia, Mallorca). Archivo Español de Arqueología, 74, 209-232.

Orfila, M., Chávez-Álvarez, E., \& Sánchez, E.H. (2014). La Orientación de las Estructuras Ortogonales de Nueva Planta en Época Romana. De la Varatio y sus Variaciones. Granada: Universidad de GranadaUniversidad de La Laguna.

Orfila Pons, M., Chávez-Álvarez, M.E., \& Sánchez E.H. (2017a). Fundaciones en época Romana. De lo intangible a lo tangible. ¿Cuándo, por qué, dónde, cómo, simbología?. Sagvntvm-PLAV[list in full], 19, 265-276.

Orfila Pons, M., Chávez-Álvarez, M.E., \& Sánchez, E.H. (2017b). Urbanizar en época Romana: ritualidad y practicidad. Propuesta de un procedimiento homologado de ejecución. SPAL[list in full], 26, $113-134$.

Peterson, J.W.M. (1992). Trigonometry in Roman cadastre. In J.Y. Guillaumin (Ed.), Mathématiques dans l'Antiquité (pp. 185-203). St.-Étiene: Université de St-Étienne.

Peterson, J.W.M. (2007). Random orientation of Roman camps. Oxford Journal of Archaeology, 26(1), 103-108.

Richardson, A. (2005). The orientation of Roman camps and forts. Oxford Journal of Archaeology, 24(4), 415-426.

Rodríguez-Antón, A. (2017). Cosmovisión y Urbanismo en la Roma Antigua: Orientación de Ciudades y Campamentos Romanos. Ph.D. Thesis. Universidad de La Laguna-Instituto de Astrofísica de Canarias.Spain

Rodríguez-Antón, A., Belmonte, J.A., \& González-García, A.C. (2016b). Romans in the Near East: the orientation of Roman settlements in present-day Jordan. Mediterranean Archaeology and Archaeometry, 16(4), 153-160.

Rodríguez-Antón, A., González-García, A.C., \& Belmonte, J.A. (2017). Estimating the reliability of digital data acquisition in Cultural Astronomy. Its use in the case of Roman North Africa. Culture and Cosmos, in press.

Rodríguez-Antón, A., González-García, A.C., \& Belmonte, J.A. (2016a). Orientation of Roman camps and forts in Britannia: reconsidering Alan Richardson's work. In F. Silva, K. Malville, T. Lomsdales, \& F. Ventura (Eds.), The Materiality of the Sky (pp. 135-144). Ceredigion: Sophia Centre Press.

Roskams, S. (2001). Excavation: Cambridge Manuals in Archaeology. Cambridge: Cambridge University Press.

Roth-Congés, A. (1996). Modalités pratiques d'implantation des cadastres Romains: quelques aspects (Quintarios claudere. Perpendere. Cultellare. Varare: la construction des cadastres sur une diagonale et 
ses traces dans le Corpus Agrimensorum). Mélanges de l'Ecole Française de Rome, Antiquité, 108(1), 299-422.

Rykwert, J. (1988). The Idea of a Town. The Anthropology of Urban Form in Rome, Italy and the Ancient World. Princeton: Princeton University Press.

Thulin, C. (1913). Corpvs Agrimensorvm Romanorvm. Opvscvla Agrimensorvm Vetervm. Studgard: Lipsia. 